Article ID: 1001-3555(2020) 01-0045-13

\title{
Highly Selective Synthesis of Trans-1-Chloro-3,3,3-Trifluoropropene by the Vapor Fluorination of $1,1,3,3$-Tetrachloropropene with HF over the Chromium Oxide-Based Catalysts
}

\author{
TIAN Mi ${ }^{1,3}$, GAO Ping ${ }^{2}$, ZHANG Rong-hui ${ }^{1,3}$, WANG Lai-lai ${ }^{1 *}$, ZHOU Wang-ying ${ }^{4}$, XIE Wen-jian \\ (1. State Key Laboratory for Oxo Synthesis and Selective Oxidation, Lanzhou Institute of Chemical Physics, \\ Chinese Academy of Sciences, Lanzhou 730000 , China; \\ 2. State Key Laboratory of Solid Lubrication, Lanzhou Institute of Chemical Physics, Chinese Academy of Sciences, \\ Lanzhou 730000, China; \\ 3. Graduate University of Chinese Academy of Sciences, Beijing, 100039, China; \\ 4. Lee \& Man Chemical Company Limited, Jiangsu 215536, China)
}

\begin{abstract}
Vapor fluorination of 1,1,3,3-tetrachloropropene ( HCC-1230za) with HF to trans-1-chloro-3,3, 3-trifluoropropene ( $\mathrm{HCFO}-1233 \mathrm{zd}(E)$ ) was investigated using the fluorinated $\mathrm{Cr}_{2} \mathrm{O}_{3}$ catalysts modified by $\mathrm{Al}^{3+}$, $\mathrm{Zn}^{2+}$, and $\mathrm{Co}^{2+}$. A highly active, selective, and long lifespan $\mathrm{Zn} / \mathrm{Cr}_{2} \mathrm{O}_{3}$ catalyst was achieved for the first time, where 99.4\% HCC-1230za conversion and 98.2\% HCFO-1233zd $(E)$ selectivity were obtained, and the selectivity to HCFO-1233zd ( $E$ ) was favored at $200{ }^{\circ} \mathrm{C}$ and HF/HCC-1230za molar ratio ( $10: 1)$. The catalysts were characterized by XRD, XPS, BET, V70 pyridine adsorption infrared spectrometer and $\mathrm{NH}_{3}$-TPD techniques. The XRD results of catalysts $\mathrm{Zn} / \mathrm{Cr}_{2} \mathrm{O}_{3}$ indicate that most of the amorphous chromium oxide and finely dispersed microcrystalline phase of $\mathrm{Cr}_{2} \mathrm{O}_{3}$ together lead to high activity and long lifespan. The conversion of HCC-1230za and the selectivity to HCFO-1233zd $(E)$ are related to the specific surface area of the fluorinated catalyst, and the higher the specific surface area of the catalyst, the higher selectivity. The XPS spectra of catalyst $\mathrm{Zn}_{\mathrm{Cr}} \mathrm{O}_{3}$ show that exterior $\mathrm{Cr}_{2} \mathrm{O}_{3}$ after $118 \mathrm{~h}$ reaction formed $\mathrm{CrO}_{x} \mathrm{~F}_{y}$ species. The number and strength of Lewis and Brønsted acid sites for $\mathrm{Zn} / \mathrm{Cr}_{2} \mathrm{O}_{3}$ catalysts after $118 \mathrm{~h}$ reaction is significantly increased than the fresh one.
\end{abstract}

Key words : fluorination; 1,1,3,3-Tetrachloropropene; HF ; tranis-1-chloro-3,3,3-trifluoropropene; fluorinated chromia CLC number: O643.36 Document code: A

Fluorine-containing hydrocarbons are commonly used as refrigerants, aerosol sprays, and foaming agents $^{[1-3]} 1,1,1,3,3$-pentafluoropropane ( HFC-245fa ) as the third generation foaming agent with an atmospheric ozone depletion potential (ODP) of 0 , the greenhouse effect potential (GWP) of 1030, faces the reality of being restricted and abandoned ${ }^{[4-6]}$. Nonflammabletrans-1-chloro-3, 3, 3-trifluoropropene ( HCFO$1233 z d(E))$ with low toxicity under normal conditionsis the fourth generation of blowing agents developed in recent years ${ }^{[7-10]}$. Its ODP and GWP are 0.000 24 and 7.0 respectively.
More particularly, it is a monomer for synthesizing polymeric materials, and a building block for making other fluorinated compounds. Compared with cis-1chloro-3,3,3-trifluoropropene ( HCFC-1233zd ( $Z$ )), HCFO-1233zd $(E)$ has higher thermos-dynamic stability, and $10 \%$ of HCFO-1233zd $(E)$ can be isomerized to $\mathrm{HCFC}-1233 \mathrm{zd}(Z)$ at $300{ }^{\circ} \mathrm{C}$ using fluorinated $\mathrm{Cr}_{2} \mathrm{O}_{3}$ catalysts $^{[11]}$.

HCFO-1233zd ( $E$ ) was synthesized in liquid phase fluorination of 1,1,1,3,3-pentachloropropane ( HCC-240fa ) with HF using Lewis acid catalysts ${ }^{[12-17]}$. However, the target product was synthe-

Received date: 2019-11-17; Revised date: 2019-12-12.

Foundation: Key Research Program of Science and Technology Project of Gansu province (No.18YF1GA124).

First author: TIAN Mi(1993-), female, Master candidate.

* Corresponding author, E-mail: wll@ licp.cas.cn, Tel: +86-931-4968161, Fax: +86931 4968129. 
sized in batches, and the reaction lead to more industrial wast and serious equipment corrosion. Special attention has been paid to vapor fluorination for the synthesis of HCFO-1233zd $(E)$ in the chemical industry, because of its potential of industrial continuous production. Until now, only several patents reported vapor fluorination routes to synthsize $\operatorname{HCFO}-1233 \mathrm{zd}(E)^{[18-22]}$. Catalysts such as $\mathrm{Cr}_{2} \mathrm{O}_{3}{ }^{[18]}, \mathrm{CrCl}_{3} / \mathrm{Al}_{2} \mathrm{O}_{3}{ }^{[19]}, \mathrm{AlF}_{3}^{[20-21]}$ and $\mathrm{Cr}-\mathrm{Ni} / \mathrm{AlF}_{3}{ }^{[22]}$ are used to reach the conversion of HCC-240fa of $100 \%$, and the selectivity of HCFO$1233 \mathrm{zd}(E)$, and catalyst lifespan are not ideal. Merkel et al introduced air into the reactants with the $\mathrm{O}_{2}$ / HCC-240fa molar ratio of $0.032: 1$, the regeneration and activation of the catalyst would be completed, and at least one more lifespan could be extended ${ }^{[23]}$. The high-valent metal halide-supported catalysts are reported to avoid rapid carbonation on the catalyst surface caused by high temperature and the formation of deep fluorinated by-products ${ }^{[24-26]}$. Though the yield of the process reached industrial application requirements, this patented technology does not address the stability of the catalyst. In addition, the usage of precious metals such as $\mathrm{Sb}$, Ta, Mo and Nb etc limited the application of this technology.

Though satisfactory selectivity of HCFO-1233zd (E) through vapor fluorination of HCC-240fa with HFhas been obtained using $\mathrm{Cr}_{2} \mathrm{O}_{3}$ fluorination catalyst at $270{ }^{\circ} \mathrm{C}$ or higher, coke on the catalyst surface accelerates the catalyst deactivation ${ }^{[18,27-29]}$. We reported highly selective synthetic route to $\mathrm{HCFO}-1233 \mathrm{zd}(E)$ by vapor fluorination of 1,1,3,3-tetrachloropropene ( $\mathrm{HCC}-1230 \mathrm{za}$ ) with $\mathrm{HF}$ over the $\mathrm{Cr}_{2} \mathrm{O}_{3}$-based catalysts. HCC-1230za was synthesized through highly selective dehydrochlorination of HCC-240fa using activated carbon. 99.4\% HCC-1230za conversion and 98.2\% HCFO-1233zd $(E)$ selectivity are obtained at $200{ }^{\circ} \mathrm{C}$, and the catalyst achieved long lifespan in this reaction.

\section{Experimental details}

\subsection{Catalyst Preparation}

The $\mathrm{M}\left(\mathrm{M}=\mathrm{Zn}^{2+}, \mathrm{Co}^{2+}, \mathrm{Al}^{3+}\right)$ modified $\mathrm{Cr}_{2} \mathrm{O}_{3}$ catalysts were prepared by a precipitation method. A detailed preparation process of the catalyst $\mathrm{Zn} / \mathrm{Al}$
$\mathrm{Cr}_{2} \mathrm{O}_{3}$ is as follows: $6.815 \mathrm{~g}(0.05 \mathrm{~mol})$ of zinc chloride, $24.15 \mathrm{~g}(0.1 \mathrm{~mol})$ of aluminum trichloride hexahydrate, and $133.2 \mathrm{~g}(0.5 \mathrm{~mol})$ of chromium trichloride hexahydrate, $\mathrm{Zn}^{2+}: \mathrm{Al}^{3+}: \mathrm{Cr}^{3+}=0.1: 0.2: 1$ $(\mathrm{mol} / \mathrm{mol} / \mathrm{mol})$, dissolved in $270 \mathrm{~mL}$ of distilled water. Subsequently, $76 \mathrm{~g}$ of $\mathrm{NaOH}(19 \mathrm{~mol} / \mathrm{L})$ was added to a solution of $\mathrm{Zn}^{2+}, \mathrm{Al}^{3+}$ and $\mathrm{Cr}^{3+}$, and magnetically stirred until precipitation occurred and allowed to stand for 24 hours. The precipitate after aging was filtered and washed with about $2000 \mathrm{~mL}$ of distilled water until the $\mathrm{pH}$ of the solution is $7 \sim 8$, then dried at $60{ }^{\circ} \mathrm{C}$ for $48 \mathrm{~h}$, followed by a calcination at $460{ }^{\circ} \mathrm{C}$ for $4 \mathrm{~h}$ in $\mathrm{H}_{2}$, and the oxide after calcination was $54.0 \mathrm{~g}$. $3 \%$ (Percent weight) of colloidal graphite were added to the calcined oxide, and grounded by a high-speed $u$ niversal pulverizer. 5\% (Percent weight) of methyl cellulose solution was added to the mixture, extruded and formed into cylindrical the final catalysts, and air-dried at room temperature. Preparation process of the catalyst $\mathrm{Co} / \mathrm{Al} / \mathrm{Cr}_{2} \mathrm{O}_{3}\left(\mathrm{Co}^{2+}: \mathrm{Al}^{3+}: \mathrm{Cr}^{3+}=0.2: 0.1: 1 \mathrm{~mol} /\right.$ $\mathrm{mol} / \mathrm{mol})$ and $\mathrm{Zn} / \mathrm{Cr}_{2} \mathrm{O}_{3}\left(\mathrm{Zn}^{2+}: \mathrm{Cr}^{3+}=1: 36 \mathrm{~mol} /\right.$ mol) are basically the same as above.

$\mathrm{Zn}^{2+}$-doped $\mathrm{Cr}_{2} \mathrm{O}_{3}$ supported over spherical $\gamma$-alumina catalyst $4 \% \mathrm{Zn} / 2 \% \mathrm{Cr} / \gamma-\mathrm{Al}_{2} \mathrm{O}_{3}$ (Percent weight) was prepared as follows: $4.880 \mathrm{~g}$ of zinc chloride and $5.930 \mathrm{~g}$ of chromium trichloride hexahydrate were dissolved in $58 \mathrm{~mL}$ of distilled water, which is used as an immersion liquid; $50 \mathrm{~g}$ spherical $\gamma-\mathrm{Al}_{2} \mathrm{O}_{3}$ carrier was added to the impregnating solution, followed by evaporating any residual water, then dried at $70{ }^{\circ} \mathrm{C}$ for $72 \mathrm{~h}$. Spherical $\gamma-\mathrm{Al}_{2} \mathrm{O}_{3}$ carrier: $\Phi 5.0 \mathrm{~mm}$, specific surface area $\geqslant 300 \mathrm{~m}^{2} / \mathrm{g}$, pore volume $\geqslant 0.40 \mathrm{~mL} / \mathrm{g}$, bulk density $0.73 \pm 0.03 \mathrm{~g} / \mathrm{mL}$. Using the same method as above to prepare catalyst $8 \% \mathrm{Zn} / 4 \% \mathrm{Cr} / \gamma-\mathrm{Al}_{2} \mathrm{O}_{3}$ ( Percent weight).

\subsection{Catalytic fluorination}

HCC-240fa is synthesized by any means well known in the literature ${ }^{[30-32]}$, and the synthesis of HCC-1230za (Scheme 1) is carried out using HCC$240 \mathrm{fa}$ as startng material as follow: $160 \mathrm{~g}$ of activated carbon is added to the quartz glass tube $(1.5 \mathrm{~m} \times 30$ $\mathrm{mm}$ ), using the method of upper feed and lower discharge. In order to ensure the smooth discharge of the 
product, a nitrogen purge is introduced during the reaction. The flow rate of nitrogen gas is $10 \mathrm{~mL} / \mathrm{min}$, the reaction temperature is controlled at $190 \sim 200{ }^{\circ} \mathrm{C}$, and the product is collected by ice salt bath cooling. During the whole reaction stage, GC analysis using a gas chromatograph (Agilent GC-7890) equipped with a flame ionization detector ( FID ) and a HP-5 $(30 \mathrm{~m})$ capillary column follows the reaction. A total of $3.0 \mathrm{~kg}$ HCC-240fa was input, the feed rate was $30 \mathrm{~mL} / \mathrm{h}$, and the unreacted HCC-240fa adsorbed by activated carbon was $0.32 \mathrm{~kg}$. The theoretical product should be 2.23 $\mathrm{kg}$, while the actual collected product HCC-1230za was $2.0 \mathrm{~kg}$. The yield is $89.6 \%$, and GC content of HCC-1230za is $>94 \%$.

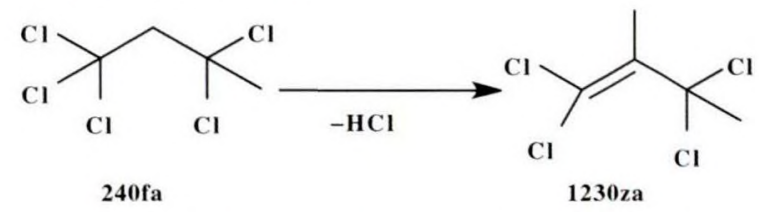

Scheme 1 Highly selective dehydrochlorination of HCC-240fa to HCC-1230za using activated carbon

Activity test of catalyst $\mathrm{Zn} / \mathrm{Cr}_{2} \mathrm{O}_{3}$ is as follows: $10 \sim 20 \mathrm{~g}$ of the catalyst was filled into 304 stainless steel reaction tube $(50 \mathrm{~cm} \times 20 \mathrm{~mm})$, heated by tube furnace at $150 \sim 300{ }^{\circ} \mathrm{C}$. Due to the high corrosiveness of $\mathrm{HF}$, the gas tightness of the reaction system needs to be checked during the experiment to prevent HF leakage. Flow rate of $\mathrm{HF}$ pre-heated in a chamber at $45{ }^{\circ} \mathrm{C}$ was carefully controlled at $60 \mathrm{~mL} / \mathrm{min}$. Using a sevenstar mass flowmeter. During the activation process, a large amount of water was generated and continuously activated for $10 \mathrm{~h}$. The activation was complete until no water is formed in the reaction tube. Subsequently, HCC-1230za feed was regulated at room temperature with a liquid pump, and the feed amount of HCC-1230za was $0.6 \mathrm{~mL} / \mathrm{min}$. The molar ratio of HCC-1230za to HF was detected by acid-base titration, and the ratio was fixed at $1: 10$. The fluorination reaction was under normal pressure at $200{ }^{\circ} \mathrm{C}$. The effluent flow from the reactor was washed with $\mathrm{NaOH}$ solution in a scrubber for the removal of $\mathrm{HCl}$ and $\mathrm{HF}$, the stream was further dried using $\mathrm{NaOH}$ pellets, and then the gaseous products were condensed to obtain a liquid sample for analysis. GC-MS ( Thermo Scientific ITQ 700 ) was applied for identity of the organic compounds formed during the reaction. The reaction products were analyzed by before mentioned gas chromatograph. The relative composition of the products is based on peak areas, therefore do not represent the absolute yields, because of difference in response factors. When the GC content of HCFO-1233zd $(E)$ decreased by more than $10 \%$, the catalyst was considered to be deactivated. Activity test of catalyst $\mathrm{Zn} / \mathrm{Al} / \mathrm{Cr}_{2} \mathrm{O}_{3}, \mathrm{Co} / \mathrm{Al} / \mathrm{Cr}_{2} \mathrm{O}_{3}$, $4 \% \mathrm{Zn} / 2 \% \mathrm{Cr} / \gamma-\mathrm{Al}_{2} \mathrm{O}_{3}$, and $8 \% \mathrm{Zn} / 4 \% \mathrm{Cr} / \gamma-\mathrm{Al}_{2} \mathrm{O}_{3}$ is basically the same as above.

We selected consecutive three hours as the time node for material balance calculation: the total feed volume was $164.0 \mathrm{~g}$, and the two-stage cooling device collected a total of $98.8 \mathrm{~g}$ of crude products and a total input of $164.0 \mathrm{~g}$. The theoretical product yield was $120.3 \mathrm{~g}$, the reaction yield was $82.1 \%$. The crude GC analysis results obtained by the two-stage cooling device contained $0.62 \%$ HCC-1230za, 91.2\% HCFC1233zd (E) , 1.7\% HCC-245fa, and 4.1\% difluorodichloropropylene. The material was lost during the reaction. The main reason was that high purity nitrogen was used in the entire experiment to dilute HF concentration to reduce safety risks, and some crude products were blown away by high purity nitrogen.

\subsection{Characterization}

The catalysts was subjected to crystal phase analysis through PANalytical X' Pert PRO Polycrystalline Powder X-ray diffractometer ( $\mathrm{Cu} \mathrm{K} \alpha, \lambda=0.15418$ $\mathrm{nm}$ ) (PANalytical BV, Almelo, Netherlands) with an angle reproducibility of $\pm 0.0001^{\circ}$, the diffraction data of $2 \theta$ in $8^{\circ} \sim 80^{\circ}$ was collected by $\theta / \theta$ scanning method with a scanning speed of $2 \% \mathrm{~min}$. Chemical compositions on the surface of samples were analyzed using an X-ray photoelectron spectrometer (XPS) (Thermo Fisher Scientific ESCALAB 250Xi) equipped with an $\mathrm{Al}$ monochromatic X-ray source ( $\mathrm{Al} \mathrm{K} \alpha=1486.6 \mathrm{eV}$, C $1 s$ was corrected to $284.8 \mathrm{eV}$ ) under room temperature in high vacuum (about $1 \times 10^{-9} \mathrm{~Pa}$ ). The $\mathrm{N}_{2}$ adsorption-desorption characterization of the samples was performed on a specific surface area analyzer Micromeritics ASAP2020 V3.04 H (Micromeritics Instrument 
Co., Ltd., Norcross, USA) at liquid nitrogen temperature $\left(-196^{\circ} \mathrm{C}\right)$. The specific surface area of the catalyst was determined using the Brunauer-Emmet-Teller (BET) method. The pore size distribution was analyzed by the adsorption-desorption isotherm through the Barret-Joyner-Halender (BJH) method using a columnar pore model.

The Brønsted and Lewis acid site of the sample were determined by V70 pyridine adsorption infrared spectrometer (Bruker, Germany) with a resolution of $4 \mathrm{~cm}^{-1}$ and an uptake range of $400 \sim 4000 \mathrm{~cm}^{-1}$. The catalyst sample was pressed into a thin sheet, placed in a quartz infrared cell, heated to $400{ }^{\circ} \mathrm{C}$ and maintained a constant temperature for evacuation pretreatment, then was degassed and dehydrated under high vacuum $\left(1 \times 10^{-3} \mathrm{~Pa}\right)$ for $2 \mathrm{~h}$, and naturally cooled to $150{ }^{\circ} \mathrm{C}$. The anhydrous pyridine was adsorbed at $150{ }^{\circ} \mathrm{C}$ for $30 \mathrm{~min}$, then heated to $400{ }^{\circ} \mathrm{C}$ to start desorption, $400{ }^{\circ} \mathrm{C}$ for $0.5 \mathrm{~h}, 150{ }^{\circ} \mathrm{C}$ for $0.5 \mathrm{~h}$, and then the PyIR spectrum was recorded on an infrared spectrometer. The temperature-programmed desorption of ammonica ( $\mathrm{NH}_{3}$-TPD) measurement was carried out on a fully automatic multifunctional dynamic adsorber instrument DAS-7200 ( Huasi Instrument Co., Ltd, China) for comparing the acidity strength of the composite catalysts. A sample of $100 \mathrm{mg}$ on the quartz glass tube (i. d. $=5 \mathrm{~mm}$ ) was first pretreated in pure $\mathrm{N}_{2}$ from 100 to
$450{ }^{\circ} \mathrm{C}$ at a rate of $10{ }^{\circ} \mathrm{C} / \mathrm{min}$, and kept at $450{ }^{\circ} \mathrm{C}$ for $2 \mathrm{~h}$. followed by cooling to $100^{\circ} \mathrm{C}$ in a flow of $\mathrm{N}_{2}(30$ $\mathrm{mL} / \mathrm{min}) . \mathrm{NH}_{3}-\mathrm{N}_{2}$ mixture $\left(10 \% \mathrm{NH}_{3}, 30 \mathrm{~mL} / \min \right)$ was introduced to the reactor for $2 \mathrm{~h}$. to allow the complete adsorption of $\mathrm{NH}_{3}$. Prior to measurement, the sample was purged with pure $\mathrm{N}_{2}(30 \mathrm{~mL} / \mathrm{min})$ to remove physically absorbed $\mathrm{NH}_{3}$ for $60 \mathrm{~min}$. Then the sample was heated in the $\mathrm{N}_{2}$ flow $(30 \mathrm{~mL} / \mathrm{min}$ ) from 100 to $850{ }^{\circ} \mathrm{C}$ with a heating rate of $10{ }^{\circ} \mathrm{C} / \mathrm{min}$., and the desorption of $\mathrm{NH}_{3}$ was recorded with a thermal conductivity detector.

\section{Results and discussion}

\subsection{Effect of HF/HCC-1230za molar ratio and re- action temperature}

It is known that HCFO-1233zd ( $E$ ) was synthesized by conducting a fluorination reaction of $\mathrm{HF}$ and HCC-240fa in the presence of catalyst $\mathrm{Cr}_{2} \mathrm{O}_{3}$ at $270 \sim$ $300{ }^{\circ} \mathrm{C}$ with the molar ratio of $\mathrm{HF} / \mathrm{HCC}-240 \mathrm{fa}$ varied from 20 to 29 . Only $82 \%$ selectivity to HCFO-1233zd $(E)$ is obtained with $\mathrm{HF} / \mathrm{HCC}-240 \mathrm{fa}$ molar ratio of $20: 1$, at $270{ }^{\circ} \mathrm{C}$, and at atmospheric pressure ${ }^{[18]}$. In our work, the reactions of HCC-1230za with anhydrous $\mathrm{HF}$ were started first using $\mathrm{Zn} / \mathrm{Cr}_{2} \mathrm{O}_{3}$ catalyst at atmospheric pressure and at $250{ }^{\circ} \mathrm{C}$. We investigated the effects of molar ratio of $\mathrm{HF} / \mathrm{HCC}-1230 \mathrm{za}$ on the selectivity to HCFO-1233zd $(E)$. Table 1 shows that the data of product distribution at different molar ratio of

Table 1 The effect of HF/HCC-1230za molar ratio on the selectivity to HCFO-1233zd $(E)^{\text {a }}$

\begin{tabular}{|c|c|c|c|c|c|c|c|}
\hline \multirow{2}{*}{ Entry } & \multirow{2}{*}{$\begin{array}{l}\mathrm{HF} / 1230 \mathrm{za} \\
(\mathrm{mol} / \mathrm{mol})\end{array}$} & \multirow{2}{*}{$\begin{array}{c}\text { Conversion/\% } \\
1230 \mathrm{za}\end{array}$} & \multicolumn{5}{|c|}{ Distribution $/ \%^{b}$} \\
\hline & & & 1233zd $(E)$ & $1233 z d(Z)$ & $1232 \mathrm{zc}$ & $245 \mathrm{fa}$ & other \\
\hline 1 & 6 & 91.0 & 55.2 & 14.2 & 11.0 & - & 10.6 \\
\hline 2 & 8 & 93.4 & 61.3 & 10.5 & 15.2 & - & 6.43 \\
\hline 3 & 10 & 98.8 & 81.5 & 0.88 & 6.50 & 2.01 & 7.90 \\
\hline 4 & 12 & 99.1 & 80.1 & 2.90 & 5.70 & 0.30 & 10.1 \\
\hline
\end{tabular}

a. Reaction conditions: at $250{ }^{\circ} \mathrm{C}$, and with contact time $10 \mathrm{~s}$; b. The distribution of products by GC analysis.

HF/HCC-1230za. The conversion of HCC-1230fa increased significantly from $91.0 \%$ to $98.8 \%$, and the selectivity to HCFO-1233zd $(E)$ increased from $55.2 \%$ to $81.5 \%$ as the molar ratio of $\mathrm{HF} / \mathrm{HCC}-1230 \mathrm{za}$ varied from 6 to 10. At the same time, the selectivity to
HCFO-1233zd $(Z)$ and HCFO-1232zc decreased drastically from $14.2 \%$ to $0.88 \%$ and $11.0 \%$ to $6.50 \%$ respectively. It suggested that the formation of unwanted side products $\mathrm{HCFO}-1233 \mathrm{zd}(Z)$ and $\mathrm{HCFO}-1232 \mathrm{zc}$ is greatly suppressed by excess HF (Scheme 2). Even if 
the molar ratio of $\mathrm{HF} / \mathrm{HCC}-1230 \mathrm{za}$ further increased beyond 10 , little influence on the selectivity to HCFO$1233 z d(E)$ and the amount of side products. So we choose HF/HCC-1230za molar ratio of $10: 1$ in the next experiment.

As shown in Table 2, the selectivity to HCFO$1233 z d(E)$ increased remarkably with the reaction temperature varied around $200{ }^{\circ} \mathrm{C}$, and the selectivity

Table 2 The effect of reaction temperature on the selectivity to HCFO-1233zd $(E)^{\text {a }}$

\begin{tabular}{cccccccc}
\hline \multirow{2}{*}{ Entry } & Temperature & Conversion $/ \%$ & \multicolumn{5}{c}{ Distribution $/ \%^{\text {b }}$} \\
\cline { 4 - 8 } & $1{ }^{\circ} \mathrm{C}$ & $1230 \mathrm{za}$ & $1233 \mathrm{zd}(E)$ & $1233 \mathrm{zd}(Z)$ & $1232 \mathrm{zc}$ & $245 \mathrm{fa}$ & other \\
\hline 1 & 150 & 91.6 & 60.4 & 1.42 & 24.5 & - & 5.28 \\
2 & 200 & 99.4 & 98.2 & - & - & 1.20 & - \\
3 & 225 & 97.9 & 87.5 & 0.30 & 6.90 & 3.16 & 0.10 \\
4 & 250 & 98.8 & 81.5 & 0.88 & 6.50 & 2.01 & 7.90 \\
5 & 275 & 97.4 & 88.1 & 0.79 & 6.00 & 1.02 & 1.53 \\
6 & 300 & 98.1 & 84.2 & 1.90 & 5.10 & 2.11 & 4.80 \\
\hline
\end{tabular}

a. Reaction conditions: with HF/HCC-1230za molar ratio of $10: 1$, and with contact time $10 \mathrm{~s}$; b. The distribution of products mby GC analysis.

to HCFO-1233zd $(E)$ declined if reaction temperature increase. At this temperature, the conversion of HCC$1230 \mathrm{za}$ is also the highest. Whereas, the selectivity to HCFO-1232zc decreased from $24.5 \%$ to $5.10 \%$ as temperature increased from 150 to $300{ }^{\circ} \mathrm{C}$. These results indicate that the reaction of HCFO-1232zc with $\mathrm{HF}$ is difficult to occur in this reaction because it requires higher energy (Scheme 2). With the reaction temperature increasing from 150 to $300{ }^{\circ} \mathrm{C}$, HCFO-1233zd $(Z)$ firstly decreased and then increased. This means that the reaction temperature has an effect on the transformation between two isomer HCFO-1233zd $(E)$ and HCFO-1233zd $(Z)$ (Scheme 2) ${ }^{[11]}$.

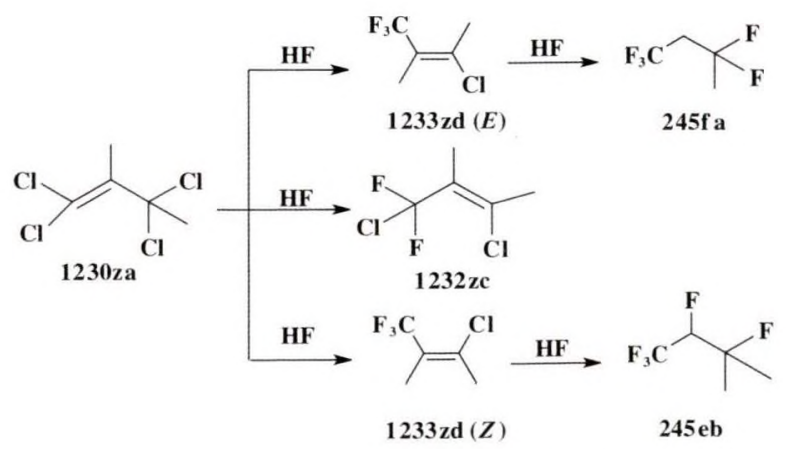

Scheme 2 Products and by-product for the fluorination of HCC-1230za with HF over $\mathrm{Zn} / \mathrm{Cr}_{2} \mathrm{O}_{3}$ catalyst

\subsection{Effect of catalyst}

Next, we observed the reactions of HCC-1230za with $\mathrm{HF}$ using different catalysts and an additional reaction of 10 -fold excess $\mathrm{HF}$ at $200{ }^{\circ} \mathrm{C}$. From Table 3, it can be seen that the use of $\mathrm{Zn} / \mathrm{Cr}_{2} \mathrm{O}_{3}$ catalyst resulted in $98.2 \%$ of HCFO-1233zd $(E$ ) (Table 3 , entries $3)$. While the use of $\mathrm{Zn} / \mathrm{Al} / \mathrm{Cr}_{2} \mathrm{O}_{3}, \mathrm{Co} / \mathrm{Al} / \mathrm{Cr}_{2} \mathrm{O}_{3}$, $4 \% \mathrm{Zn} / 2 \% \mathrm{Cr} / \gamma-\mathrm{Al}_{2} \mathrm{O}_{3}$ and $8 \% \mathrm{Zn} / 4 \% \mathrm{Cr} / \gamma-\mathrm{Al}_{2} \mathrm{O}_{3}$ catalyst revealed $72.9 \%, 68.4 \%, 83.7 \%$ and $88.3 \%$ of HCFO-1233zd $(E)$ respectively (Entries 1, 2, 4, and $5)$. The catalyst $\mathrm{Zn} / \mathrm{Cr}_{2} \mathrm{O}_{3}$ was more effective in yielding HCFO-1233zd $(E)$ and avoiding HCFO-1233zd $(Z)$ than other catalysts. Therefore, the addition of $\mathrm{Zn}^{2+}$ to $\mathrm{Cr}_{2} \mathrm{O}_{3}$ significantly increases the selectivity of HCFO-1233zd (E) (Table 3, Entry 3).

Because the stability of the catalyst is crucial in practical application ${ }^{[23-26]}$, long term reaction were conducted using the catalysts $\mathrm{Zn} / \mathrm{Al} / \mathrm{Cr}_{2} \mathrm{O}_{3}, \mathrm{Co} / \mathrm{Al} /$ $\mathrm{Cr}_{2} \mathrm{O}_{3}$, and $\mathrm{Zn} / \mathrm{Cr}_{2} \mathrm{O}_{3}$ at $200{ }^{\circ} \mathrm{C}$ and contact time $10 \mathrm{~s}$, respectively ( Table 3 ). The conversions remained constant ( >99\%) and the selectivity of HCFO-1233zd $(E)$ gradually declined from $98.2 \%$ to $88.2 \%$ at a time on stream of $118 \mathrm{~h}$ using $\mathrm{Zn} / \mathrm{Cr}_{2} \mathrm{O}_{3}$ catalyst. This indicates that $\mathrm{Zn} / \mathrm{Cr}_{2} \mathrm{O}_{3}$ catalyst is stabled uring the $118 \mathrm{~h}$ testing, and the selectivity to HCFO-1233zd $(E)$ is satisfactory ( Table 3, Entry 3 ). Using $\mathrm{Zn} / \mathrm{Al} / \mathrm{Cr}_{2} \mathrm{O}_{3}$ and $\mathrm{Co} / \mathrm{Al} / \mathrm{Cr}_{2} \mathrm{O}_{3}$ catalysts after 112 and $120 \mathrm{~h}$ reaction, the conversions not significantly changed as compared with the initial of $95.2 \%$ and $94.3 \%$, and the 
Table 3 The reactions of $\mathrm{HCC}-1230 \mathrm{za}$ with $\mathrm{HF}$ using different catalysts ${ }^{\mathrm{a}}$

\begin{tabular}{|c|c|c|c|c|c|c|c|c|}
\hline \multirow{2}{*}{ Entry } & \multirow{2}{*}{ Catalyst } & \multirow{2}{*}{$\begin{array}{c}\text { Conversion } \% \\
1230 \mathrm{za}\end{array}$} & \multicolumn{5}{|c|}{ Distribution $/ \%^{b}$} & \multirow{2}{*}{$\begin{array}{c}\text { Lifespan } \\
\qquad / \mathrm{h}\end{array}$} \\
\hline & & & $1233 z d(E)$ & 1233zd $(Z)$ & $1232 \mathrm{zc}$ & $245 \mathrm{fa}$ & other & \\
\hline 1 & $\mathrm{Zn} / \mathrm{Al} / \mathrm{Cr}_{2} \mathrm{O}_{3}$ & 95.2 & 72.9 & 3.02 & 13.2 & - & 6.10 & 112 \\
\hline 2 & $\mathrm{Co} / \mathrm{Al} / \mathrm{Cr}_{2} \mathrm{O}_{3}$ & 94.3 & 68.4 & 4.90 & 17.0 & - & 4.04 & 120 \\
\hline 3 & $\mathrm{Zn} / \mathrm{Cr}_{2} \mathrm{O}_{3}$ & 99.4 & 98.2 & - & - & 1.20 & - & 118 \\
\hline 4 & $4 \% \mathrm{Zn} / 2 \% \mathrm{Cr} / \gamma-\mathrm{Al}_{2} \mathrm{O}_{3}$ & 99.8 & 83.7 & 5.08 & 10.0 & - & 0.50 & 19.0 \\
\hline 5 & $8 \% \mathrm{Zn} / 4 \% \mathrm{Cr} / \gamma-\mathrm{Al}_{2} \mathrm{O}_{3}$ & 99.9 & 88.3 & 5.00 & 5.70 & - & 0.88 & 13.5 \\
\hline
\end{tabular}

a. Reaction conditions : with HF/HCC-1230za molar ratio of $10: 1$, at $200{ }^{\circ} \mathrm{C}$, and with contact time $10 \mathrm{~s}$; b. The distribution of products by GC analysis.

selectivety to $\mathrm{HCFO}-1233 \mathrm{zd}(E)$ were $62.9 \%$ and $58.4 \%$ ( Table 3, Entries 1 and 2 ) respectively. Although $4 \% \mathrm{Zn} / 2 \% \mathrm{Cr} / \gamma-\mathrm{Al}_{2} \mathrm{O}_{3}$ and $8 \% \mathrm{Zn} / 4 \% \mathrm{Cr} / \gamma-$ $\mathrm{Al}_{2} \mathrm{O}_{3}$ catalysts suffered the most severe deactivation compared with other catalysts, the results of the study demonstrate the beneficial effect of zinc loading to chromium-containing alumina on increasing the selectivity of HCFO-1233zd ( $E$ ) ( Table 3, Entries 4 and 5 ).

The generation of active $\mathrm{CrO}_{x} \mathrm{~F}_{y}$ species could be approached by adding $\mathrm{Zn}^{2+}, \mathrm{Co}^{2+}$ and $\mathrm{Al}^{3+}$ in the $\mathrm{Cr}_{2} \mathrm{O}_{3}$-based catalysts. For example, Lee et al ${ }^{[33]}$ found that $\mathrm{MgF}_{2} / \mathrm{Cr}_{2} \mathrm{O}_{3}$ catalyst was more active than $\mathrm{Cr}_{2} \mathrm{O}_{3}$ catalyst for the synthesis of 1,1,1,2-tetrafluoroethane ( HFC-134a ) from 2-chloro-1, 1, 1-trifluoroethane ( $\mathrm{HCFC}-133 \mathrm{a}$ ), which was related to $\mathrm{MgCrO}_{x} \mathrm{~F}_{y}$ species generated through the reaction of $\mathrm{CrF}_{3}$ and $\mathrm{MgF}_{2}$. The vacant sites of $\mathrm{CrF}_{3}$ or $\mathrm{CrF}_{x}(\mathrm{OH})_{3-x}$ are believed to be responsible for the $L$ acidity, whereas $B$ acidity can be attributed to the presence of hydroxyl group. $\mathrm{Zn} /$ $\mathrm{Cr}_{2} \mathrm{O}_{3}$ catalyst has the suitable acidity site distribution and strength of $\mathrm{B}$ acid and $\mathrm{L}$ acid, and which give high stable and selectivity under optimum fluorination conditions.

The reactions of HCC-1230za with HF over $\mathrm{Zn}$ / $\mathrm{Cr}_{2} \mathrm{O}_{3}$ catalyst prepared at different calcination temperature were carried out in $\mathrm{N}_{2}$ or $\mathrm{H}_{2}$ atmosphere. In preparation process of the catalysts designed as $\mathrm{Zn} / \mathrm{Cr}_{2} \mathrm{O}_{3}$ $350-\mathrm{N}_{2}, \mathrm{Zn} / \mathrm{Cr}_{2} \mathrm{O}_{3}-350-\mathrm{H}_{2}, \mathrm{Zn} / \mathrm{Cr}_{2} \mathrm{O}_{3}-460-\mathrm{N}_{2}, \mathrm{Zn} /$ $\mathrm{Cr}_{2} \mathrm{O}_{3}-460-\mathrm{H}_{2}, \quad \mathrm{Zn} / \mathrm{Cr}_{2} \mathrm{O}_{3}-560-\mathrm{N}_{2}, \quad \mathrm{Zn} / \mathrm{Cr}_{2} \mathrm{O}_{3}-560-$ $\mathrm{H}_{2}, \mathrm{Zn} / \mathrm{Cr}_{2} \mathrm{O}_{3}-600-\mathrm{N}_{2}$, and $\mathrm{Zn} / \mathrm{Cr}_{2} \mathrm{O}_{3}-600-\mathrm{H}_{2}$, the precipitated slurry was calcined at 350, 460, 560, and $600{ }^{\circ} \mathrm{C}$ for $4 \mathrm{~h}$ in $\mathrm{N}_{2}$ or $\mathrm{H}_{2}$ atmosphere to obtain the final catalysts, respectively. The results are summarized in Table 4. The reaction of HCC-1230za with HF resulted in $81.9 \%$ of HCFO-1233zd $(E)$ over catalyst

Table 4 The reactions of $\mathrm{HCC}$-1230za with $\mathrm{HF}$ using $\mathrm{Zn} / \mathrm{Cr}_{2} \mathrm{O}_{3}$ catalyst prepared at

different calcination temperature under $\mathrm{H}_{2}$ or $\mathrm{N}_{2}$ atmosphere ${ }^{a}$

\begin{tabular}{|c|c|c|c|c|c|c|c|}
\hline \multirow{2}{*}{ Entry } & \multirow{2}{*}{ Catalyst } & \multirow{2}{*}{$\begin{array}{c}\text { Conversion } \% \\
1230 \mathrm{za}\end{array}$} & \multicolumn{5}{|c|}{ Distribution $/ \%^{b}$} \\
\hline & & & 1233zd $(E)$ & $1233 \mathrm{zd}(Z)$ & $1232 \mathrm{zc}$ & $245 \mathrm{fa}$ & other \\
\hline 1 & $\mathrm{Zn} / \mathrm{Cr}_{2} \mathrm{O}_{3}-350-\mathrm{N}_{2}$ & 93.9 & 81.9 & 0.20 & 2.50 & - & 9.30 \\
\hline 2 & $-\mathrm{H}_{2}$ & 98.0 & 87.0 & 5.72 & 0.56 & - & 4.70 \\
\hline 3 & $-460-\mathrm{N}_{2}$ & 99.7 & 87.3 & 2.19 & 6.06 & - & 4.10 \\
\hline 4 & $-\mathrm{H}_{2}$ & 99.4 & 98.2 & - & - & 1.20 & - \\
\hline 5 & $-560-\mathrm{N}_{2}$ & 99.1 & 85.6 & 6.00 & 4.60 & - & 2.90 \\
\hline 6 & $-\mathrm{H}_{2}$ & 99.3 & 84.0 & 7.04 & 4.10 & 0.80 & 3.40 \\
\hline 7 & $-600-\mathrm{N}_{2}$ & 97.7 & 80.0 & 5.70 & 6.40 & - & 5.60 \\
\hline 8 & $-\mathrm{H}_{2}$ & 98.3 & 82.0 & 10.1 & 2.40 & - & 3.80 \\
\hline
\end{tabular}

a. Reaction conditions: with HF/HCC-1230za molar ratio of $10: 1$, at $200{ }^{\circ} \mathrm{C}$, and with contact time $10 \mathrm{~s}$; b. The distribution of products by GC analysis. 
$\mathrm{Zn} / \mathrm{Cr}_{2} \mathrm{O}_{3}-350-\mathrm{N}_{2}$, while $87.0 \%$ of HCFO-1233zd (E) was gained over catalyst $\mathrm{Zn} / \mathrm{Cr}_{2} \mathrm{O}_{3}-350-\mathrm{H}_{2}$ ( Entry 1 vs Entry 2, Table 4$)$. The selectivity of HCFO$1233 z d(E)$ steadily increased from $81.9 \%$ (at calcined $350{ }^{\circ} \mathrm{C}$ ) to $98.2 \%$ (at calcined $460{ }^{\circ} \mathrm{C}$ ) ( Entry $1,2,3$, and 4, Table 4). While the selectivity decreased from $98.2 \%$ to $82.0 \%$ (entry $4,5,6,7$, and 8 , Table 4) if calcination temperature gradually increased to $600{ }^{\circ} \mathrm{C}$. It can be seen that the calcination temperature has an effect on the selectivity to HCFO1233zd $(E)$, and the catalytic precursor calcined under $\mathrm{H}_{2}$ was more effective than that under $\mathrm{N}_{2}$ atmosphere (Entry 3 vs Entry 4, and Entry 5 vs Entry 6, Table 4). These results are consistent with Brunet' $\mathrm{s}^{[34]}$ and Xie's ${ }^{[35]}$. Brunet et al ${ }^{[34]}$ investigated the effects of activation temperature and atmosphere $\left(\mathrm{N}_{2}\right.$, $\mathrm{H}_{2}$ or air) of $\mathrm{Cr}_{2} \mathrm{O}_{3}$ catalyst on the synthesis of HFC134a from HCFC-133a. They concluded that Cr species of reversible oxidation state are the active sites of reaction. Xie's group demonstrated the calcination temperature have great influence on the crystalline size, surface acid sites and the molar fraction of $F$ in the catalyst $^{[35]}$. With increasing calcination temperature, $\mathrm{Cr}_{2} \mathrm{O}_{3}$ translates from amorphous structure into crystalline phase, and the intensity of the diffraction peaks gradually becomes stronger. On the other hand, the molar fraction of $\mathrm{F}$ in the catalyst and the amount of

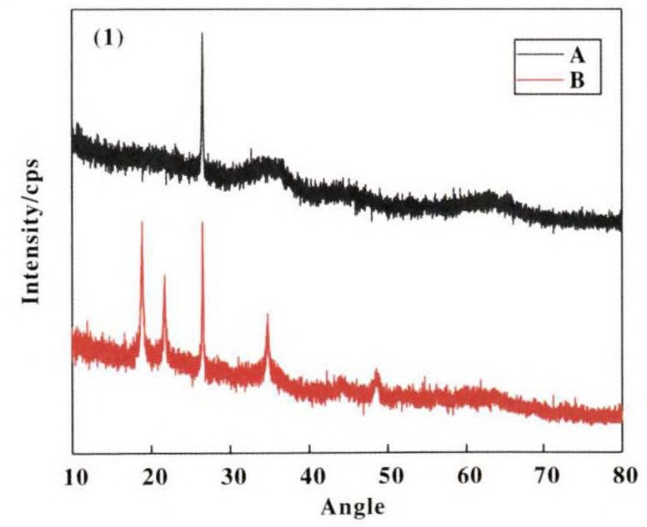

surface acid sites decrease with increasing calcination temperature.

\subsection{Product distribution studies}

Bsed on the obtained products and by-products several plausible reaction pathways (Scheme 2) were inferred. The product HCFO-1233zd $(E)$ can be obtained by the fluorination of HCC-1230za with HF in the presence of a suitable catalyst. Of course, this is an oversimplified reaction path that does not fully reflect the actual reactions that may occur under the established catalytic conditions. From Scheme 2, it can be speculated that the actual reaction system may be more complicated when considering the isomers of several possible intermediates. Besides the expected HCFO1233zd $(E)$, the other minor components formed are 1,3-dichloro-3,3-difluoropropene ( HCFO-1232zc), and with trace amounts of 1,3,3-trichloro-3-fluoropropene (HCFO-1231zb) , 1,3,3-trichloro-1,1-difluoropropane ( HCFC-242fb ), 3, 3-dichloro-1, 1, 1-trifluoropropane (HCFC-243fc) , 1,1,1,2,3-penta- fluoropropane (HFC-245eb), and HFC-245fa in all experiments. The selectivities to the trace amounts and other unknown products are not discussed in this work.

\subsection{Characterization of the composite catalysts}

XRD analyses were performed to characterize the bulk properties of $\mathrm{Zn} / \mathrm{Cr}_{2} \mathrm{O}_{3}$ catalysts ( Fig. 1). The results show that under the preparation conditions of

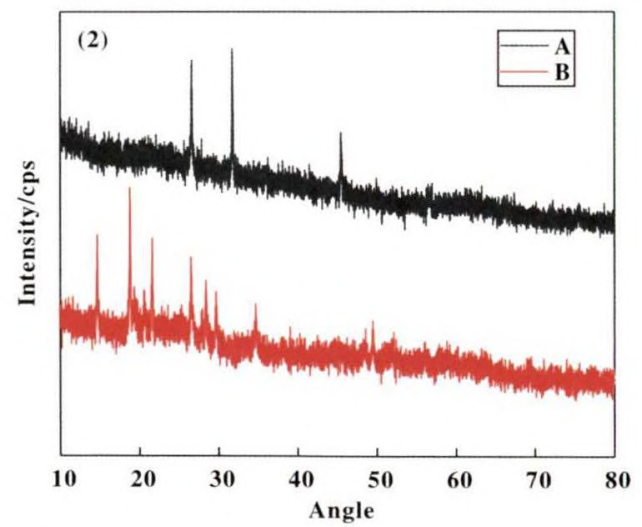

Fig.1 XRD patterns of the catalysts: (1) (A) the fresh catalyst $\mathrm{Zn} / \mathrm{Cr}_{2} \mathrm{O}_{3}$; (B) catalyst $\mathrm{Zn} / \mathrm{Cr}_{2} \mathrm{O}_{3}$ after 118 h reaction, and (2) (A) the fresh catalyst $\mathrm{Co} / \mathrm{Al} / \mathrm{Cr}_{2} \mathrm{O}_{3}$; (B) catalyst $\mathrm{Co} / \mathrm{Al} / \mathrm{Cr}_{2} \mathrm{O}_{3}$ after $120 \mathrm{~h}$ reaction

$\mathrm{Zn} / \mathrm{Cr}_{2} \mathrm{O}_{3}$ catalyst, the fresh catalyst (Fig.1 (1) (a)) is mainly amorphous $\mathrm{Cr}_{2} \mathrm{O}_{3}$, but it contains microcrystalline phase of $\mathrm{Cr}_{2} \mathrm{O}_{3}$ with good dispersibility, which size is estimated to be between several nanometers. The XRD pattern shows a diffraction pattern of microcrystalline phase of $\mathrm{Cr}_{2} \mathrm{O}_{3}$. The maximum peak width at half 
height is wider than that of single crystal $\mathrm{Cr}_{2} \mathrm{O}_{3}$. In the Fig.1(1) (a), $2 \theta$ is a peak of graphite at $25.2^{\circ}$, and the $2 \theta$ of the diffraction peak of crystalline $\mathrm{Cr}_{2} \mathrm{O}_{3}$ is $44.4^{\circ}$, while the peaks at $34.4^{\circ}$ and $36.2^{\circ}, 63.2^{\circ}$ and $65.0^{\circ}$ overlap. However, no diffraction peak related to zinc species such as $\mathrm{ZnO}$ could be detected, suggesting the zinc species might be highly dispersed. The XRD pattern of $\mathrm{Zn} / \mathrm{Cr}_{2} \mathrm{O}_{3}$ catalyst after $118 \mathrm{~h}$ reaction ( Fig. 1(1) (b)) is not significantly changed as compared with the fresh catalyst (Fig.1(1) (a)). The results (Fig. 1 (1) (a) and (b)) indicated that $\mathrm{Zn} / \mathrm{Cr}_{2} \mathrm{O}_{3}$ catalysts was very stable during the fluorination process. But a new microcrystalline phase of $\mathrm{CrF}_{3}$ $\left(18.8^{\circ}, 21.6^{\circ}\right.$, and $\left.34.6^{\circ}\right)$ was found in the Fig.1(1) (b). Although Cho et $\mathrm{al}^{[36]}$. Found that amorphous $\mathrm{CrO}_{3}$ with high dispersion was more advantage for the fluorination synthesis of HFC-134a from HCFC-133a than the crystalline $\mathrm{Cr}_{2} \mathrm{O}_{3}$, in our work the XRD results, as well as the evaluation results of $\mathrm{Zn} / \mathrm{Cr}_{2} \mathrm{O}_{3}$ catalyst activity indicate that most of the amorphous $\mathrm{Cr}_{2} \mathrm{O}_{3}$ and finely dispersed microcrystalline phase of $\mathrm{Cr}_{2} \mathrm{O}_{3}$ together lead to high activity, high selectivity, and high stability of the catalyst. Catalyst $\mathrm{Co} / \mathrm{Al} / \mathrm{Cr}_{2} \mathrm{O}_{3}$ after $120 \mathrm{~h}$. Reaction and the fresh one were almost amorphous $\mathrm{Cr}_{2} \mathrm{O}_{3}$ ( Fig. 1(2) (a) and 1(b)), which again confirmed our results.

The large surface area catalysts are desired in gas phase fluorination synthesis of HFC-134a from HCFC133a, but the normal fluorinated metal oxides or metal fluorides have a small surface area $\left(<50 \mathrm{~m}^{2} \cdot \mathrm{g}^{-1}\right)^{[34]}$. BET-surface area, pore size and pore volume of the catalyst used here are summarized in Table 5. The

Table 5 The data of BET-surface area, pore size, and pore volume of the catalysts

\begin{tabular}{ccccc}
\hline Entry & Catalyst & $S_{\mathrm{BET}} /\left(\mathrm{m}^{2} \cdot \mathrm{g}^{-1}\right)$ & Pore size $/ \mathrm{nm}$ & Pore volume $/\left(\mathrm{cm}^{3} \cdot \mathrm{g}^{-1}\right)$ \\
\hline 1 & $\mathrm{Zn} / \mathrm{Cr}_{2} \mathrm{O}_{3}$ & 188 & 5.28 & 0.249 \\
$2^{\mathrm{a}}$ & - & 448 & 2.46 & 0.276 \\
3 & $\mathrm{Zn} / \mathrm{Al} / \mathrm{Cr}_{2} \mathrm{O}_{3}$ & 182 & 4.35 & 0.177 \\
$4^{\mathrm{b}}$ & - & 18.2 & 3.65 & 0.017 \\
5 & $\mathrm{Co} / \mathrm{Al} / \mathrm{Cr}_{2} \mathrm{O}_{3}$ & 169 & 4.69 & 0.245 \\
$6^{\mathrm{c}}$ & - & 66.9 & 2.69 & 0.045 \\
\hline
\end{tabular}

a. $\mathrm{Zn} / \mathrm{Cr}_{2} \mathrm{O}_{3}$ catalyst after $118 \mathrm{~h}$ reaction; b. $\mathrm{Zn} / \mathrm{Al} / \mathrm{Cr}_{2} \mathrm{O}_{3}$ catalyst after $112 \mathrm{~h}$ reaction; c. $\mathrm{Co} / \mathrm{Al} / \mathrm{Cr}_{2} \mathrm{O}_{3}$ catalyst after $120 \mathrm{~h}$ reaction.

specific surface areas are 188,182 , and $169 \mathrm{~m}^{2} \cdot \mathrm{g}^{-1}$ for the fresh $\mathrm{Zn} / \mathrm{Cr}_{2} \mathrm{O}_{3}, \mathrm{Zn} / \mathrm{Al} / \mathrm{Cr}_{2} \mathrm{O}_{3}$, and $\mathrm{Co} / \mathrm{Al}$ $\mathrm{Cr}_{2} \mathrm{O}_{3}$ catalysts, respectively. This indicating that the specific surface area of these composite catalysts calcined at $460{ }^{\circ} \mathrm{C}$ in $\mathrm{H}_{2}$ atmosphere is larger than the fluorination catalyst already reported. The specific surface area of $\mathrm{Zn} / \mathrm{Cr}_{2} \mathrm{O}_{3}$ catalyst after $118 \mathrm{~h}$ reaction is $448 \mathrm{~m}^{2} \cdot \mathrm{g}^{-1}$. However, the specific surface areas are 18.2 and $66.9 \mathrm{~m}^{2} \cdot \mathrm{g}^{-1}$ for $\mathrm{Zn} / \mathrm{Al} / \mathrm{Cr}_{2} \mathrm{O}_{3}$ after $112 \mathrm{~h}$ reaction and $\mathrm{Co} / \mathrm{Al} / \mathrm{Cr}_{2} \mathrm{O}_{3}$ catalyst after $120 \mathrm{~h}$ reaction, respectively. Thus, the conversion of HCC-1230za and the selectivity to HCFO-1233zd $(E)$ are related to the specific surface area of the $\mathrm{Zn} / \mathrm{Cr}_{2} \mathrm{O}_{3}$ catalyst.

XPS spectra were used to identify the surface $\mathrm{Cr}$ species of catalyst $\mathrm{Zn} / \mathrm{Cr}_{2} \mathrm{O}_{3}, \mathrm{Co} / \mathrm{Al} / \mathrm{Cr}_{2} \mathrm{O}_{3}$, and $\mathrm{Zn}$ / $\mathrm{Al} / \mathrm{Cr}_{2} \mathrm{O}_{3}$ ( Fig. 2). For the fresh $\mathrm{Zn} / \mathrm{Cr}_{2} \mathrm{O}_{3}$ catalyst, two kinds of $\mathrm{Cr}$ species can be attributed respectively (Fig.2 (1) (a ) ) ${ }^{[37]}$. Then, the spectrum of the Cr $2 p$ for $\mathrm{Zn} / \mathrm{Cr}_{2} \mathrm{O}_{3}$ catalyst after $118 \mathrm{~h}$ reaction, $\mathrm{Co} / \mathrm{Al} /$ $\mathrm{Cr}_{2} \mathrm{O}_{3}$ catalyst after $120 \mathrm{~h}$. reaction, and $\mathrm{Zn} / \mathrm{Al} / \mathrm{Cr}_{2} \mathrm{O}_{3}$ catalyst after $112 \mathrm{~h}$. Reaction became broadening, and were shifted to higher binding energy (Fig.2 (1) (b), (2) (a), and (2) (b) ). The broad Cr $2 p_{3 / 2}$ peak of $\mathrm{Zn} / \mathrm{Cr}_{2} \mathrm{O}_{3}$ sample was fitted by three components at $578.6,579.9$ and $582.7 \mathrm{eV}$, respectively. The peak at $578.6 \mathrm{eV}$ is assigned to the $\mathrm{Cr}(\mathrm{OH})_{3}$ phase. The peak at $579.9 \mathrm{eV}$ is ascribed to the $\mathrm{Cr}_{2} \mathrm{O}_{3}$ phase. Finally, the weak peak at $582.7 \mathrm{eV}$ is likely due to $\mathrm{CrO}_{x} \mathrm{~F}_{y}$ 
(1)

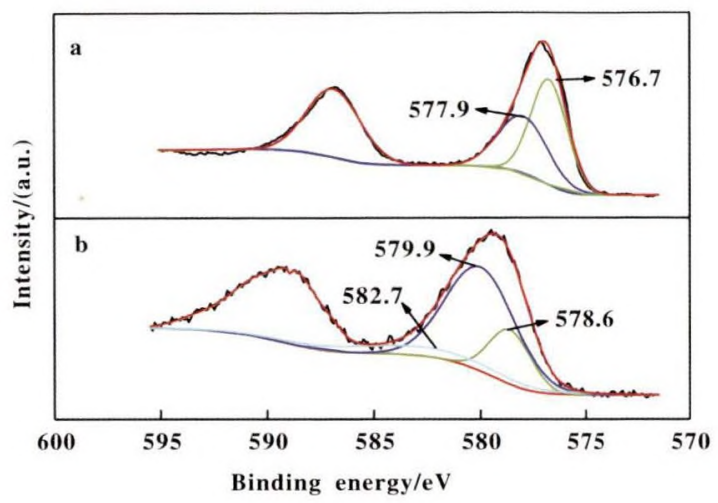

(3)

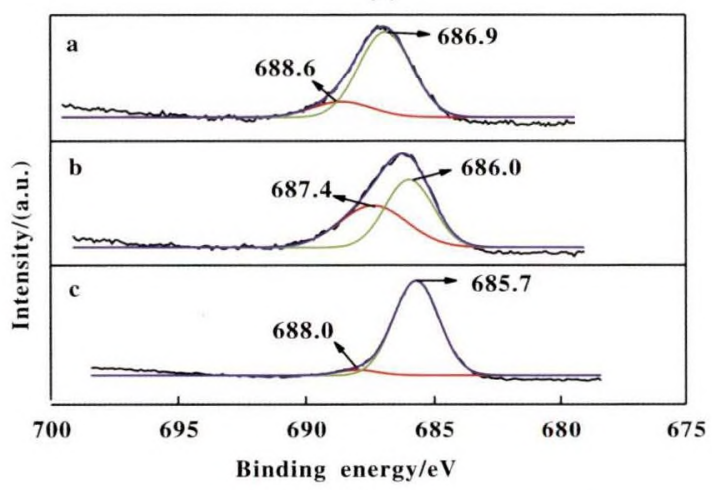

(2)

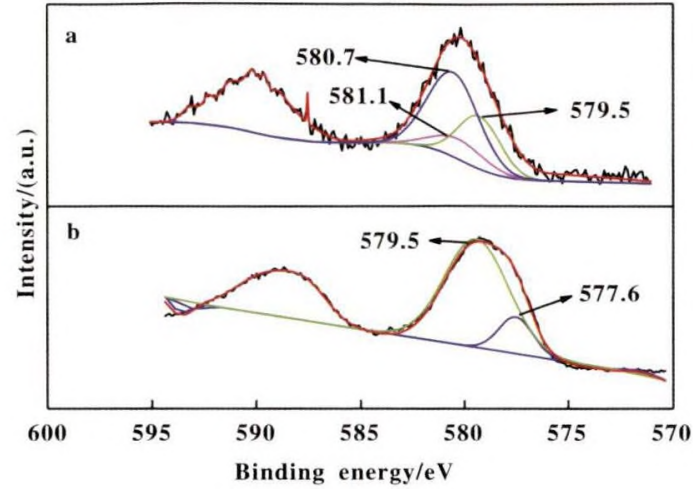

(4)

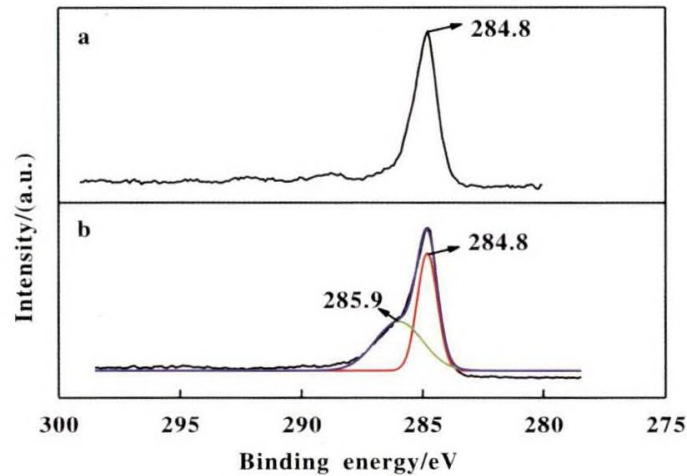

Fig.2 (1) XPS spectra of the $\mathrm{Cr} 2 p$ for $\mathrm{Zn} / \mathrm{Cr}_{2} \mathrm{O}_{3}$ catalysts (a) before and (b) after $118 \mathrm{~h}$, reaction;

(2) XPS spectra of the $\mathrm{Cr} 2 p$ for (a) $\mathrm{Co} / \mathrm{Al} / \mathrm{Cr}_{2} \mathrm{O}_{3}$ catalyst after $120 \mathrm{~h}$, reaction, and (b) $\mathrm{Zn} / \mathrm{Al} / \mathrm{Cr}_{2} \mathrm{O}_{3}$ catalyst after $112 \mathrm{~h}$, reaction; (3) XPS spectra of the F $1 s$ for (a) $\mathrm{Zn} / \mathrm{Cr}_{2} \mathrm{O}_{3}$ catalyst after $118 \mathrm{~h}$, reaction,

(b) $\mathrm{Co} / \mathrm{Al} / \mathrm{Cr}_{2} \mathrm{O}_{3}$ catalyst after $120 \mathrm{~h}$, reaction, and (c) $\mathrm{Zn} / \mathrm{AV} / \mathrm{Cr}_{2} \mathrm{O}_{3}$ catalyst after $112 \mathrm{~h}$, reaction; (4) XPS spectra of the $\mathrm{C} 1 s$ for $\mathrm{Zn} / \mathrm{Cr}_{2} \mathrm{O}_{3}$ catalysts (a) before and (b) after $118 \mathrm{~h}$ reaction.

species $^{[38]}$. The $\mathrm{Cr}(\mathrm{OH})_{3}$ phase could be formed through the reaction of $\mathrm{Cr}_{2} \mathrm{O}_{3}$ with hydroxyl or water because the samples were exposed in air before the XPS testing.

The high-resolution F $1 s$ core level spectra in Fig. 2 show two peaks at $685.7 \sim 686.9$ and $687.4 \sim 688.6$ $\mathrm{eV}$ for $\mathrm{Zn} / \mathrm{Cr}_{2} \mathrm{O}_{3}, \mathrm{Co} / \mathrm{Al} / \mathrm{Cr}_{2} \mathrm{O}_{3}$, and $\mathrm{Zn} / \mathrm{Al} / \mathrm{Cr}_{2} \mathrm{O}_{3}$ catalysts after $118,120,112 \mathrm{~h}$, reaction, respectively. The peak at $685.7 \sim 686.9 \mathrm{eV}$ in three catalysts indicates the presence of $\mathrm{CrF}_{3}$. The relatively weaker peak at $687.4 \sim 688.6 \mathrm{eV}$ is ascribed to a new chromium fluoride phase $\mathrm{CrO}_{x} \mathrm{~F}_{y}$ with higher oxidation states than $\mathrm{Cr}^{3+}$. For $\mathrm{Zn} / \mathrm{Cr}_{2} \mathrm{O}_{3}$ catalyst after $118 \mathrm{~h}$ reaction, C $1 s$ peaks were deconvoluted into two peaks with binding energies at about 284.8 and $285.9 \mathrm{eV}$ respectively, attributing to the $\mathrm{C}$ and $-\left(\mathrm{CF}_{3} \mathrm{CHCHCl}\right)_{n}-$.
Clearly, carbon deposition over $\mathrm{Zn} / \mathrm{Cr}_{2} \mathrm{O}_{3}$ catalyst after $118 \mathrm{~h}$ reaction are higher than that of the fresh $\mathrm{Zn} /$ $\mathrm{Cr}_{2} \mathrm{O}_{3}$ catalyst. Especially, carbon deposition derived from polymerization over $\mathrm{Zn} / \mathrm{Cr}_{2} \mathrm{O}_{3}$ catalyst after $118 \mathrm{~h}$ reaction are higher than the fresh $\mathrm{Zn} / \mathrm{Cr}_{2} \mathrm{O}_{3}$ catalyst respectively (based on the $-\left(\mathrm{CF}_{3} \mathrm{CHCHCl}\right)_{n}-$ ) ( Fig. 2 (4) (a) and (4) (b)). The differences in $\mathrm{Cr} 2 p_{3 / 2}$, $\mathrm{F} 1 s$, and $\mathrm{C} 1 s$ core level spectra suggest changes in the catalyst surface properties after/during the reaction, and the exterior $\mathrm{Cr}_{2} \mathrm{O}_{3}$ were strongly interacted with HF during the vapor fluorination process. Moreover, the presence of $\mathrm{CrO}_{x} F_{y}$ species is important to the catalytic performance (both activity and selectivity $)^{[37,39-40]}$. This result was consistent with Blanchard et $a l^{[41]}$, observation that in a set of temperature-programmed oxidation, the fluorination activity of $\mathrm{Cr}_{2} \mathrm{O}_{3}$ is 
greatly influenced by the presence of $\mathrm{Cr}$ in higher oxidation state.

During the fluorination reaction, the Brønsted and Lewis acid site distribution of the catalyst $\mathrm{Zn} / \mathrm{Cr}_{2} \mathrm{O}_{3}$ surface directly affect the catalytic properties of $\mathrm{F} / \mathrm{Cl}$

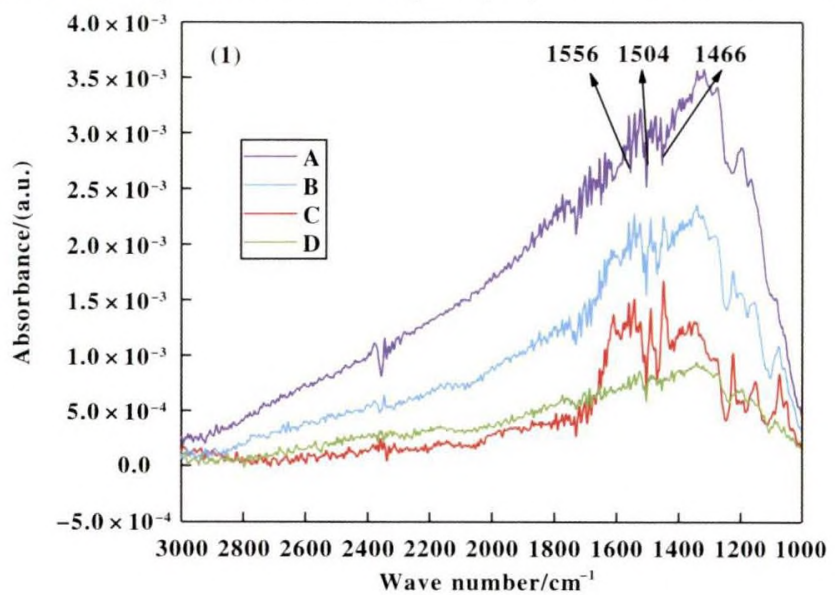

exchange reactions ${ }^{[35]}$. Py-IR spectrum of the catalyst $\mathrm{Zn} / \mathrm{Cr}_{2} \mathrm{O}_{3}$ are shown in Fig.3 (1). It can be observed from Fig. 3 that the characteristic peaks of 1466, 1504 and $1556 \mathrm{~cm}^{-1}$ on the spectrum belong to the $\mathrm{L}$ acid and $\mathrm{B}$ acid sites respectively. The absorption peak at

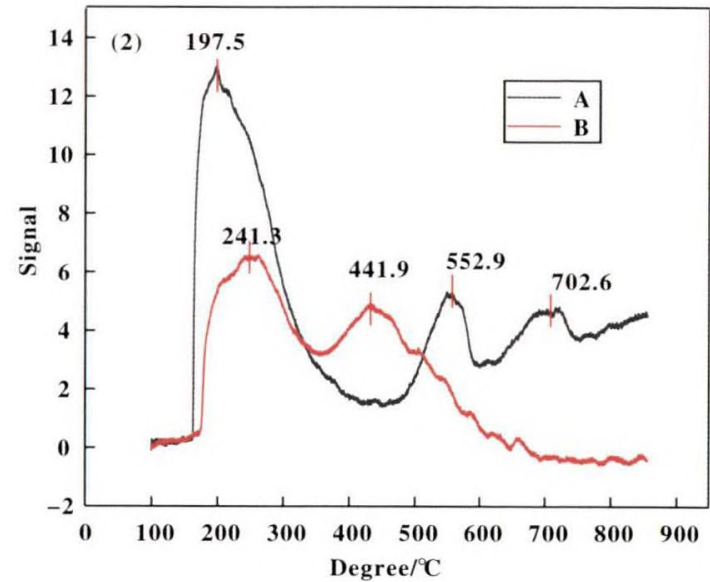

Fig.3 (1) Py-IR spectrum of $\mathrm{Zn} / \mathrm{Cr}_{2} \mathrm{O}_{3}$ catalyst: (a) desorption of pyridine of catalyst after $118 \mathrm{~h}$ reaction at $400{ }^{\circ} \mathrm{C}$,

(b) desorption of pyridine of catalyst after $118 \mathrm{~h}$ reaction at $150{ }^{\circ} \mathrm{C}$, (c) adsorption of pyridine of catalyst after $118 \mathrm{~h}$ reaction at $150{ }^{\circ} \mathrm{C}$, (d) adsorption of pyridine of the fresh catalyst at $150{ }^{\circ} \mathrm{C}$; (2) $\mathrm{NH}_{3}-\mathrm{TPD}$ profiles of $\mathrm{Zn} / \mathrm{Cr}_{2} \mathrm{O}_{3}$ catalyst: (a) after $118 \mathrm{~h}$ reaction, and (b) the fresh

$1466 \mathrm{~cm}^{-1}$ is a characteristic peak of the coordination complex of pyridine and Lewis acid site, belonging to the Lewis acid site of the catalyst. The absorption peak at $1556 \mathrm{~cm}^{-1}$ is a characteristic peak of pyridinium ions, belonging to the Brønsted acid site of the catalyst. And the absorption peak at $1504 \mathrm{~cm}^{-1}$ is a characteristic peak of both the coordination complex of pyridine and Lewis acid site and pyridinium ions, belonging to the Lewis and Brønsted acid site of the catalyst. Comparing Fig.3(1) (a), (b), (c) and (d), it is easy to find that both the catalyst $\mathrm{Zn} / \mathrm{Cr}_{2} \mathrm{O}_{3}$ after $118 \mathrm{~h}$ reaction and the fresh catalyst possess the Brønsted and Lewis acid site, and the numbers of acid sites of the catalyst $\mathrm{Zn} / \mathrm{Cr}_{2} \mathrm{O}_{3}$ after $118 \mathrm{~h}$ reactionis significantly increased than the fresh catalyst.

The fresh catalyst $\mathrm{Zn} / \mathrm{Cr}_{2} \mathrm{O}_{3}$ and the catalyst after $118 \mathrm{~h}$ reaction were characterized by the $\mathrm{NH}_{3}$-TPD technique (Fig. 3 (2)). The $\mathrm{NH}_{3}$-TPD profiles reveal that for the catalyst after $118 \mathrm{~h}$ reaction, three $\mathrm{NH}_{3}$ desorption peaks were detected with peak temperature at 197.5 , 552.9, and $702.6{ }^{\circ} \mathrm{C}$, respectively, corresponding to the weak and strong acid sites (Fig.3(2), (a) ) , and for the fresh catalyst shows two broad desorption peaks at temperature range of $190 \sim 550{ }^{\circ} \mathrm{C}$ (Fig.3(2), b), which suggests that the catalyst contain mild acidic sites. The $\mathrm{NH}_{3}$ desorption peak at $197.5{ }^{\circ} \mathrm{C}$ of the catalyst after $118 \mathrm{~h}$, reaction is higher and wilder than the corresponding $\mathrm{NH}_{3}$ desorption peak at $241.3{ }^{\circ} \mathrm{C}$ of the fresh catalyst. The two ammonia desorption peaks of the catalyst after $118 \mathrm{~h}$, reaction at 552.9 and $702.6{ }^{\circ} \mathrm{C}$ are weaker. By contrast, one ammonia desorption peaks of the fresh catalyst at $441.9{ }^{\circ} \mathrm{C}$ is weaker. This indicates that acidic sites over the catalyst after $118 \mathrm{~h}$ reaction are more strong than those over the fresh catalyst. As noted previously, the composite catalyst $\mathrm{Zn} / \mathrm{Cr}_{2} \mathrm{O}_{3}$ after $118 \mathrm{~h}$ reaction has suitable acidity sites distribution and strength, and which present high stable and selectivity under optimum fluorination conditions.

\section{Conclusion}

In summary, the catalyst $\mathrm{Zn} / \mathrm{Cr}_{2} \mathrm{O}_{3}$ is the most effective catalyst among tested catalysts $\mathrm{Zn} / \mathrm{Al} / \mathrm{Cr}_{2} \mathrm{O}_{3}$, $\mathrm{Co} / \mathrm{Al} / \mathrm{Cr}_{2} \mathrm{O}_{3}, 4 \% \mathrm{Zn} / 2 \% \mathrm{Cr} / \gamma-\mathrm{Al}_{2} \mathrm{O}_{3}$, and $8 \% \mathrm{Zn} /$ 
$4 \% \mathrm{Cr} / \gamma-\mathrm{Al}_{2} \mathrm{O}_{3}$. The addition of $\mathrm{Zn}^{2+}$ to $\mathrm{Cr}_{2} \mathrm{O}_{3}$ significantly increases the selectivity of HCC-1230za with HF to HCFO-1233zd ( $E$ ). The heat treatment conditions in the preparation of the catalyst $\mathrm{Zn} / \mathrm{Cr}_{2} \mathrm{O}_{3}$ has a great influence to the properties of the catalyst. When calcined at $460{ }^{\circ} \mathrm{C}$ under a $\mathrm{H}_{2}$ atmosphere, it achieved at 99.4\% the conversion of HCC-1230za and $98.2 \%$ the selectivity of HCFO-1233zd ( $E$ ). The HCFO-1233zd (E) formation can be evidently increased with $\mathrm{HF} /$ HCC-1230za (molar ratio of $10: 1$ ) at $200{ }^{\circ} \mathrm{C}$. The results of product distribution proved the beneficial effects of molar ratio of reactants and temperature on selectivity to $\mathrm{HCFO}-1233 \mathrm{zd}(E)$ using $\mathrm{Zn} / \mathrm{Cr}_{2} \mathrm{O}_{3}$ catalyst. The XRD results of the catalyst $\mathrm{Zn} / \mathrm{Cr}_{2} \mathrm{O}_{3}$ shows that most of the amorphous chromium oxide and finely dispersed microcrystalline phase of $\mathrm{Cr}_{2} \mathrm{O}_{3}$ together lead to high activity and long lifespan. The conversion of HCC-1230za and the selectivity to HCFO-1233zd ( $E$ ) are related to the specific surface area of the fluorinated catalyst. Also the higher the specific surface area of the catalyst, the higher the catalytic activity and selectivity are. The XPS spectra of the catalyst $\mathrm{Zn} / \mathrm{Cr}_{2} \mathrm{O}_{3}$ probably indicates that the exterior $\mathrm{Cr}_{2} \mathrm{O}_{3}$ after $118 \mathrm{~h}$ reaction were strongly interacted with $\mathrm{HF}$ during the fluorination process and formed $\mathrm{CrO}_{x} \mathrm{~F}_{y}$ species. The number and strength of Lewis and Brønsted acid sites for the catalyst $\mathrm{Zn} / \mathrm{Cr}_{2} \mathrm{O}_{3}$ after $118 \mathrm{~h}$ reaction is significantly increased than the fresh catalysts.

\section{Acknowledgments}

This work was supported by Key Research Program of Science and Technology Project of Gansu province (No.18YF1GA124). We thank Min Deng and Zhao Yanxia for our work.

\section{References :}

[1] Zhai Y, Poss A J, Singh R R. Stereoselective synthesis of cis-1-chloro-3, 3, 3-trifluoropropene [ J ]. Tetra Lett, 2016, 57(3): 396-398.

[2] Li Y C, Luo Z Y. The development of foaming agent forpolyurethane rigid foam and the challenge of HCFC14lbsubstitution[ J]. Poly Indus, 2014, 29(5) : 1-4.

[3] Engels H W, Pirkl H G, Albers R, et al. Polyurethanes: versatile materials and sustainable problem solvers for today's challenges $[\mathrm{J}]$. Angew Chen Int Ed, 2013, 52
(36) : 9422-9441.

[4] Zheng L F. Some environmental friendly foaming technique of polyurethane foam $[\mathrm{J}]$. Poly Indus, 2016, 31 (4) : 44-46.

[5] Zhao B, Lu J Y, Mao W. Progress in fluorocarbonblowing agent $[\mathrm{J}]$. Chem Ind Eng Prog, 2014, 33 (7): 18641870 .

[6] Yuan C G, Du C M, Xu H. Properties of rigid polyurethane foam with environmentally friendly blowing agent [J]. Chin Plastics, 2014, 28(2) : 45-50.

[7] Hulse R, Singh R, Pokrovski K, et al. Converting ( E) 1chloro-3,3, 3-trifluoropropene into ( Z ) 1-chloro-3, 3, 3trifluoropropene, useful as e. g. refrigerants, comprises providing feed stream comprising (E) 1-chloro-3,3,3-trifluoropropene and contacting stream with heated surface. $\mathrm{US}[\mathrm{P}], 0152504 \mathrm{~A} 1$.

[8] Chen B B, Bonnet P, Elsheikh M, et al. Azeotrope-like composition, useful e.g. as heat transfer composition for transferring heat from an article, as a blowing agent, solvent, propellants, and as foamable composition, comprises E-1-chloro-3, 3, 3-trifluoropropene and isopropanol. $\mathrm{US}[\mathrm{P}], 0041529$ A1.

[9] Basu R, Cook K, Bement L, et al. Azeotrope-like compositions comprising trans-chloro-3,3,3-trifluoropropene. $\mathrm{US}[\mathrm{P}], 0102273 \mathrm{~A} 1$.

[10] Xiong L Y, Xing Y H, Wang J X. The application of trans-1-chloro-3, 3, 3-trifluoropropene blowing agent in polyurethanerigid foam $[\mathbf{J}]$. Poly Indus, 2016, 31 (3) : 26-29.

[11] Nair H, Poss A J, Singh R R, et al. Process for cischloro-2,3,3-trifluoropropene. US [P], 8404907 B2.

[12] Wilmet V, Janssens F. Hydro-fluorination of chlorinated hydrocarbons. US $[\mathrm{P}], 6362383 \mathrm{~B} 1$.

[13] Tung H S, Ulrich K, Merkel D. Low temperature production of 1-chloro-3,3 ,3-trifluoropropene( HCFC-1233ZD). $\mathrm{US}[\mathrm{P}], 6844475 \mathrm{~B} 1$.

[14] Hibino Y, Yoshikaw S, Sakyu F. Production method for 1-chloro-3, 3, 3-trifluoropropene. US [P] , 104039745A.

[15] Wang H Y, Merkel D C. Integrated process to co-produce 1,1,1,3,3-pentafluoropropane, trans-1-chloro-3,3,3-trifluoropropene and trans-1,3,3,3-tetrafluoropropene. CN [P] , 103476736A.

[16] Pokrovski K A, Merkel D C. Tong continuous low-temperature process to produce trans-1-chloro-3, 3, 3-trifluoropropene. US $[\mathrm{P}], 103189339 \mathrm{~A}$.

[17] Cottrell S, Tung H S, Pokrovskl K. Integrated process for the production of 1-chloro-3, 3,3-trifluoropropene. US 
$[\mathrm{P}], 0083316 \mathrm{~A} 1$.

[18] Tong X S. Vapor phase process for making 1, 1, 1, 3, 3pentafluoropropane and 1-chloro-3,3,3-trifluoropropene. $\mathrm{US}[\mathrm{P}], 5710352$.

[19] Yoshikaw S. Method for producing 1, 1, 1, 3, 3-pentafluoropropane. US $[\mathrm{P}], 6198010 \mathrm{~B} 1$.

[20] Tatsuo N, Hirokazu A, Akinori Y. Preparation of 1, 1, 1, 3, 3-pentafluoropropyl. US [P], 1206394A.

[21] Satoru Y, Fuyuhiko S, Yasuo H. Manufacture of 1, 3,3, 3-tetrafluoro propene as e.g. protective gas of pharmaceuticals and agrochemicals, involves reacting 1-chloro-3,3, 3-trifluoro propene with hydrogen fluoride in gas phase and in presence of fluorinated catalyst. JP $[\mathrm{P}]$, $10067693 \mathrm{~A}$.

[22] Lantz A, Wendlinger L, Requireme B. Synthesis of 1chloro-3, 3, 3-trifluoropropylene and its fluoridation to 1,1,1,3,3-pentafluoropropylene. US $[\mathrm{P}], 1166479 \mathrm{~A}$.

[23] Merkel D C, Pokrovski K A, Tong X S. Catalyst life improvement for vapor phase manufacture of 1-chloro-3,3, 3-trifluoropropene. US $[\mathrm{P}], 102933532 \mathrm{~A}$.

[24] Yasuo H, Pyouichi T, Shuozou K. Method for producing fluorinated propane. EP $[\mathrm{P}], 0103578$.

[25] a. Lv J, Zhang W, Wang B. Method for producing 1chloro-3, 3, 3-trifluoropropene. CN [P], 101028994B. b. Lian Chen-shuai( 连晨帅), Dai Rong (代容), Tian Ren(田韧), et al. The effect of preparation method on catalytic properties over $\mathrm{Ni}-\mathrm{Cu}$ bimetallic catalysts for steam Re forming of ethanol ( Ni-Cu 双金属催化剂上乙 醇水蒸气重整制氢研究一制备方法对催化性能的影 响) [J].J Mol Catal(China) (分子催化)，2019, 33 (4): 297-308.

c. Chai Ying-jie(柴应洁), Feng He(冯鹤), Cui Yanbin(崔艳斌), et al. Structure control of nickel-based perovskite catalyst and its application in methane dry reforming (镍基钲钛矿型催化剂的结构调控及其在甲 烷干重整反应中的应用) [ J $]$. J Mol Catal (China) (分子催化)，2018, 32(3)：228-239.

[26] Quan H D, Yang H E, Masanori T. Preparation of 1,1, 1, 3, 3-pentafluoropropane ( HFC-245fa) by using a SbF5-attached catalyst [J]. J Fluorine Chem, 2007, 128 (3) : 190-195.

[27] Merkel D C, Pokrovski K A, Tung H S. Azeotropic or azeotrope-like composition used as intermediate for producing fluorinated organic compound e.g. 1-chloro-3,3,3trifluoropropene, comprises 1,3,3-trichloro-3-fluoroprop1 -ene and hydrogen fluoride. US $[\mathrm{P}], 0245548$.

[28] Merkel D C, Tung H S. Producing 1-chloro-3,3,3-triflu- oropropene used as e.g. refrigerant, by dehydrochlorinating 1,1,3,3-tetrachloro-1-fluoropropane in presence of basic solution to form 1,3,3-trichloro-3-fluoropropene and fluorinating with hydrogen fluoride. US $[\mathrm{P}]$, 0004035 .

[29] Bartholomew C H. Mechanisms of catalyst deactivation [J]. Appl Catal A, 2001, 212(1/2): 17-60.

[30] Xu X T, Zhang W X. Kineties of synthesis of 1,1,1,3, 3-pentachloropropane $[\mathrm{J}]$. CIESC J, 2014, 65 ( 1): $176-181$.

[31] Boutevin B, Pietrasanta Y, Taha M. Télomères monofonctionnels du chlorure de vinyle-I: Synthèse et caractérisation d'étalons de télomères du chlorure de vinyle $[\mathrm{J}]$. Eur Polym, 1982, 18(8): 675-678.

[32] Kotora M, Hajek M. Selective additions of polyhalogenated compounds to chlogo substituded ethenes catalyzed by a copper complex $[\mathrm{J}]$. React Kinet Catal Lett, 1991, 44 (2): 415-417.

[33] Lee H, Jeong H D, Chung Y S, et al. Fluorination of $\mathrm{CF}_{3} \mathrm{CH}_{2} \mathrm{Cl}$ over $\mathrm{Cr}-\mathrm{Mg}$ fluoride catalyst: The effect of temperature on the catalyst deactivation $[\mathrm{J}] . J$ Catal, 1997, 169(1): 307-316.

[34] Brunet S, Requieme B, Matouba E, et al. Characterization by temperature-programmed reduction and by temperature-programmed oxidation (TPR-TPO) of chromium ( III ) oxide-based catalvsts: Correlation with the catalytic activity for hydrofluoroalkane synthesis $[\mathrm{J}]$. J Catal, 1995, 152(1): 70-74.

[35] Xie Z, Fan J, Cheng Y, et al. $\mathrm{Cr}_{2} \mathrm{O}_{3}$ catalysts for fluorination of 2-chloro-3,3,3-trifluoropropene to 2,3,3,3-tetrafluoropropene $[\mathrm{J}]$. Indus Eng Chem Res , 2013, 52 (9) : 3295-3299.

[36] Cho D H, Kim Y G, Chung M J, et al. Preparation and characterization of magnesia-supported chromium catalysts for the fluorination of 1,1,1-trifluoro-2-chloroethane (HCFC-133a) [J]. Appl Catal B, 1998, $18(3 / 4)$ : $251-261$.

[37] Chung Y S, Lee H, Jeong H D, et al. Enhanced catalytic activity of air-calcined fluorination catalyst $[\mathrm{J}] . J$ Catal, 1998, 175(2): 220-225.

[38] Loustaunau A, Fayolle-Romelaer R, Celerier S, et al. Catalytic fluorination of various chlorinated hydrocarbons by $\mathrm{HF}$ and a chromium based catalyst: Effect of the presence of zinc $[\mathbf{J}]$. Catal Lett, 2010, 138(3/4) : 215223.

[39] Adamczyk B, Boese O, Weiher N, et al. Fluorine modified chromium oxide and its impact on heterogeneously 
catalyzed fluorination reactions $[\mathrm{J}]$. J Fluorine Chem, 2000, 101(2): 239-246.

[40] Cheng Y X, Fan J L, Xie Z Y, et al. Effects of M-promoter $(\mathrm{M}=\mathrm{Y}, \mathrm{Co}, \mathrm{La}, \mathrm{Zn})$ on $\mathrm{Cr}_{2} \mathrm{O}_{3}$ catalysts for fluorination of perchloroethylene [J]. J Fluorine Chem, 2013, 156: $66-72$.
[41] Barrault J, Brunet S, Requieme B, et al. Preparation of substitutes for CFCs catalytic properties of chromia for halogen exchange involving hydrogen fluoride and trifluorochloroethane $[J]$. J Chem Soc Chem Comm , 1993, 4: 374-375.

\title{
改性三氧化二铬催化 $1,1,3,3$-四氯丙烯氟化高选择性 合成反式-1-氯-3,3,3-三氟丙烯研究
}

\author{
田 密 ${ }^{1,3}$, 高 平 ${ }^{2}$, 张㭉慧 ${ }^{1,3}$, 王来来 ${ }^{1 *}$, 周旺鹰 4 , 谢文健 ${ }^{4}$ \\ (1. 中国科学院兰州化学物理研究所 炭基合成与选择氧化国家重点实验室, 甘肃兰州 730000 ; \\ 2. 中国科学院兰州化学物理研究所 固体润滑国家重点实验室, 甘肃兰州 730000 ; \\ 3. 中国科学院大学, 北京 100039 ; \\ 4. 江苏理文化工有限公司, 江苏 常熟 215536)
}

\begin{abstract}
摘要: 反式-1-氯-3,3,3-三氟丙烯 (HCFO-1233zd $(E))$ 是近年来正在研发的第 4 代发泡剂, 其大气臭氧消耗潜能值 为 0.00024 , 温室效应潜能值为 7.0 , 毒性低, 常态下不燃, 使用安全; 它也是合成含氟精细化工品的中间体, 以 及合成氟树脂和氟弹性体的单体. 我们制备了 $\mathrm{Al}, \mathrm{Zn}$, Co 改性的 $\mathrm{Cr}_{2} \mathrm{O}_{3}$ 催化剂, 将其成功应用于 1,1,3,3-四氯丙 烯 (HCC-1230za) 与氟化氢反应中, 高选择性地合成 HCFO-1233zd $(E)$, 复合催化剂 $\mathrm{Zn} / \mathrm{Cr}_{2} \mathrm{O}_{3}$ 显示高稳定性, 其中 HCC-1230za 转化率高达 99.4\%, HCFO-1233zd(E) 的选择性高达 $98.2 \%$. 反应条件诸如反应物 HF/HCC-1230za 的 摩尔比和反应温度等对产物分布有显著影响. 在相对较低的温度 $\left(200{ }^{\circ} \mathrm{C}\right)$ 和较大的 $\mathrm{HF} / \mathrm{HCC}-1230 \mathrm{za}$ 摩尔比 (10：1) 下, 对 HCFO-1233zd (E) 的选择性有利. 通过 XRD, XPS, BET 和 V70 吡啶吸附红外光谱技术对复合催化 剂 $\mathrm{Zn} / \mathrm{Cr}_{2} \mathrm{O}_{3}$ 进行了表征. XRD 结果表明, 催化剂中大多数无定形 $\mathrm{Cr}_{2} \mathrm{O}_{3}$ 和高度分散微晶相 $\mathrm{Cr}_{2} \mathrm{O}_{3}$ 共同导致催化剂 的高活性和高稳定性. HCC-1230 za 的转化率与预氟化处理催化剂 $\mathrm{Zn} / \mathrm{Cr}_{2} \mathrm{O}_{3}$ 的比表面积有关, 催化剂的比表面积 越高, 催化活性越高. XPS 光谱表明, 在预氟化过程中, 表面铬氧化物可能与 F 原子强烈相互作用, 从而导致 Cr 原子的化学环境发生广泛变化. V70 吡啶吸附红外光谱和氨-程序升温脱附技术结果证明尚未失活的催化剂 Lewis 酸和Brønsted 酸中心的数目和强度与新制备的催化剂相比明显提高.
\end{abstract}

关键词: 氟化; 1,1,3,3-四氯丙烯; 氟化氢; 反式-1-氯-3,3,3-三氟丙烯; 氟化三氧化二铬 


\section{Gas-Phase Catalytic Isomerization of Tran-Chlorochloroole-} fin to Cis-Chlorochloroolefin and Its Potential Mechanism

SHANG Lei, WU Ming-liang

J. Mol. Catal. (China) 2020, 34( 1): 028 035

Gas phase catalysis is a green chemical method. $\mathrm{Al}_{2} \mathrm{O}_{3}$ was found to isomerize trans-CFC1316 to cis-CFC1316 by gas-phase catalysis. In order to understand isomerization mechanism, XRD,

$\mathrm{CeO}_{2}$ Supported NiCo Bimetal Catalyzes Liquid Phase Hydrogenation of Phenol

LU Jin-zhi, MA Zhan-wei, WEI Xue-mei, ZHANG Qin-sheng, HU Bin

J. Mol. Catal.( China) 2020, 34( 1): 036 044

A series of NiCo bimetal catalysts with different NiCo mass ratios supported on $\mathrm{CeO}_{2}$ nanorod $\left(r-\mathrm{CeO}_{2}\right)$ were prepared by impregnation method. These catalysts were investigated for the hydrogenation of phenol to cyclohexanol, and characterized by TEM, XRD, TPR, TPD and XPS. The results indicate that the activity of NiCo bimetallic catalyst at a suitable mass ratio ( $\mathrm{Ni}$ :

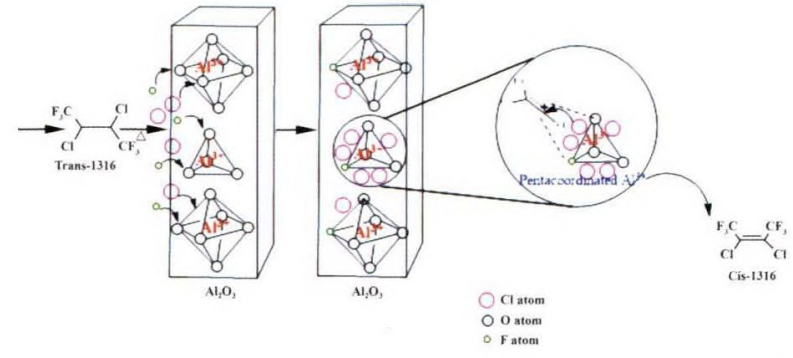

TPD, BET, XPS, GC and GC-MS were used. On this basis, the potential mechanism of isomerization is proposed.

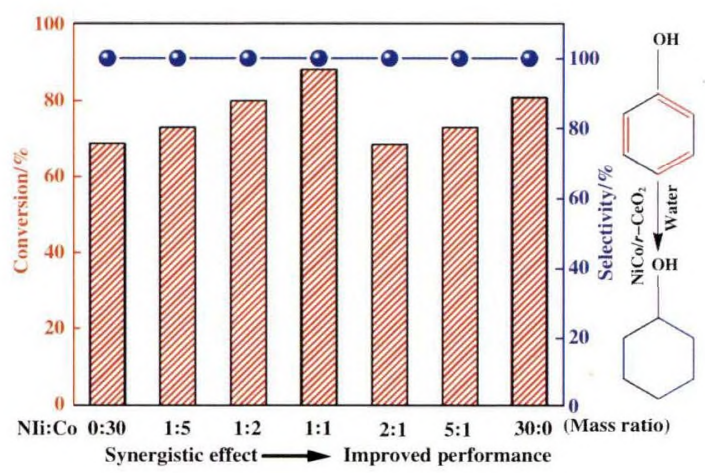

$\mathrm{Co}_{\mathrm{O}}=1: 1$ ) is higher than that of the corresponding single metal catalysts, which can attribute to the addition of cobalt increases the dispersion of $\mathrm{Ni}$ species and modulates the surface properties of active sites on the catalysts.

Highly Selective Synthesis of Trans-1-Chloro-3, 3, 3-Trifluoropropene by the Vapor Fluorination of 1, 1, 3, 3-Tetrachloropropene with HF over the Chromium Oxide-Based Catalysts

TIAN Mi, GAO Ping, ZHANG Rong-hui, WANG Lai-lai, ZHOU Wang-ying, XIE Wen-jian

J. Mol. Catal. (China) 2020, 34( 1): 045 057

The $\mathrm{Cr}_{2} \mathrm{O}_{3}$-based catalysts modified by $\mathrm{Al}^{3+}, \mathrm{Zn}^{2+}, \mathrm{Co}^{2+}$ were successfully applied in the vapor fluorination of $1,1,3,3$ tetrachloropropene (HCC-1230za) with HF for the synthesis of trans-1-chloro-3, 3, 3-trifluoropropene ( $\mathrm{HCFO}-1233 \mathrm{zd}(E))$.

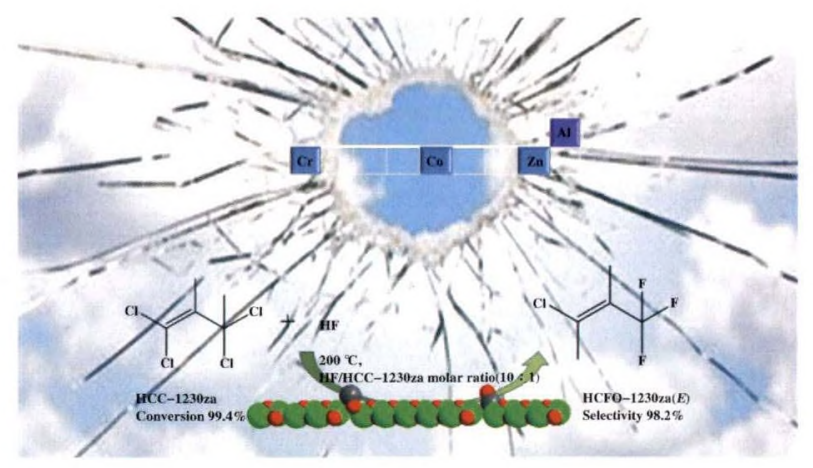

Under optimal conditions, 99.4\% HCC-1230za conversion and 98.2\% HCFO-1233zd $(E)$ selectivity were obtained using $\mathrm{Zn} /$ $\mathrm{Cr}_{2} \mathrm{O}_{3}$ catalyst. 